\title{
EFFECT OF RADIATION, HYDROGEN PEROXIDE AND CHLORINE ON BACTERIAL
} DECONTAMINATION OF BROILER CARCASSES

\author{
H.F.A. EL-DOSOKY and SHERIN S. MOSTAFA
}

Animal Health Research Institute, Mansoura Lab., Mansoura, Egypt.

\section{ABSTRACT}

Received at: 12/9/2012

Accepted: 27/11/2012
Eighty random samples of broiler chicken carcasses were collected from an automatic poultry slaughtering plant in Dakahlia Governorate just after washing in the chiller and divided into four groups each group consists of 20 chicken carcasses which subdivided into two subgroups (ten carcasses for each subgroup). The $1^{\text {st }}$ group left as a control. The $2^{\text {nd }}$ group decontaminated with $25 \mathrm{ppm}$ chlorine (first subgroup), the other subgroup decontaminated with $50 \mathrm{ppm}$ chlorine for three minutes. The results were reduced significantly when compared with corresponding control statistically for both concentrations. The $3^{\text {rd }}$ group were decontaminated with $1 \%$ hydrogen peroxide (first subgroup) and the other subgroup decontaminated with $2 \%$ hydrogen peroxide for two minutes Where the Aerobic Plate Counts (APCs), Most Probable Number (MPN) count and the counts of Staph.aureus were reduced significantly when compared with corresponding controls $(\mathrm{P}<0.05)$. The $4^{\text {th }}$ group decontaminated with gamma rays first subgroup irradiated with 2 Kilo Gray(KGy) and the other subgroup irradiated with $3 \mathrm{KGy}$. The irradiation results of APCs were reduced significantly $(\mathrm{P}<0.05)$ after irradiation with $2 \mathrm{KGy}$ and $3 \mathrm{KGy}$, MPN count were reduced significantly $(\mathrm{P}<0.05)$ after irradiation by $2 \mathrm{KGy}$ and no growth after irradiation with $3 \mathrm{KGy}$ and the counts of Staph.aureus were reduced significantly $(\mathrm{P}<0.05)$ after irradiation with $2 \mathrm{KGy}$ and no growth after irradiation by $3 \mathrm{KGy}$.

Key words: Broiler, irradiation, Staph.aureus, hydrogen peroxide.

\section{INTRODUCTION}

Poultry meat is a nutritious food consumed all over the world because of its relatively low cost and low fat content, however it is highly perishable with a relatively short shelflife even where it is kept under refrigeration. Although poultry constitute an excellent source of high quality and easily digested protein it is liable to transmit different types of potentials to consumers Zahra, (2001). Many attempts were applied to reduce the microbial findings and level of poultry meat contamination through using variable chemicals like sodium hypochlorite which resulted in significant reduction in the number of microorganisms, Ismail et al. (2001). One of the newly emerging technologies to ensure microbiological safety of meat is radiation processing Kanatt et al. (2005). The safety and efficacy of irradiation in food preservation has been thoroughly demonstrated world wide Pelezar et al. (1997). The radiation doses required to inactivate $90 \%$ of the common foodborne pathogens associated with meat and poultry are in the range of 1-4KGy, Thayer et al.
(1993). Contamination of poultry carcasses with Staph. aureus usually occurs through handling by human, if such products are left without refrigeration for several hours or cooled slowly in refrigerator, growth of Staph.aureus and enterotoxin formation may occur, growth of Staph.aureus in the product is favoured by lack of competitive bacteria which are destroyed by heat, Bryan (1980). The aerobic plate counts (APCs), Most Probable Number of Coliforms (MPN) and counts of Staph.aureus in chicken carcasses collected from different poultry shop were $3.38 \times 10^{6} \pm 1.02 \times 10^{6}, 2.58 \times 10^{4} \pm 0.9 \times 10^{4}$ and $9.95 \times 10^{3} \pm$ $1.56 \times 10^{3} \mathrm{cfu} / \mathrm{gm}$ respectively, Morshdy et al. (2008). While the counts were $6.1 \pm 0.1,2.7 \pm 0.1$ and $3.7 \pm 0.1$ $\log _{10} \mathrm{cfu} / \mathrm{gm}$ respectively in fresh whole chicken broiler carcasses, Mira; Eskandar, (2007) also Mahmoud; Hammouda (2006) examined thigh and breast and found that APCs and Staph.aureus count were $1.4 \times 10^{6} \pm 4 \times 10^{5}$ and $6 \times 10^{5} \pm 2 \times 10^{4}$ while Staph.aureus count were $8.9 \times 10^{3} \pm 0.3 \times 10^{3}$ and $2.7 \times 10^{3} \pm 1.7 \times 10^{4}$ respectively. May (1974) mentioned that final rinsing of commercially slaughterd broilers with $25 \mathrm{ppm}$ chlorine resulted in significant reduction in TVCs., Whyte et al. (2001) proved that final 
rinsing of poultry carcasses with $25 \mathrm{ppm}$ chlorine reduce TVCs from $4.98 \pm 0.38$ to $4.52 \pm 0.24$ and Enterobacteriaceae from $3.37 \pm 0.31$ to $3.16 \pm 0.16$ $\log _{10} \mathrm{cfu} / \mathrm{gm}$. Commercial chlorine chiller on poultry carcasses during processing reduce APCs, Staph.aureus from $6.2 \times 10^{4}$ and $1.4 \times 10^{4}$ to $2.4 \times 10^{4}$ and $6 \times 10^{3} \mathrm{cfu} / \mathrm{gm}$ respectively Gelis; Kabul (2006), while Karen et al. (2010) mentioned that significant reduction in APCs and Coliforms by 50 ppm chlorine rinsing for three minutes the reduction were 0.4 and $0.21 \log _{10} \mathrm{cfu} / \mathrm{gm}$ respectively. Hydrogen peroxide is highly unstable and breaksdown into water and single oxygen molecule which is strong oxidizing and disinfecting agent Black et al. (2008), also several investigators concluded that chlorine and hydrogen peroxide were most frequently used in commercial poultry processing as antimicrobials due to their availability, low cost and efficacy Bolder, (1997); Hugas; Tsigarida (2008); Northcutt; Jone (2004), also Mostafa (2010) concluded that Hydrogen peroxide $0.1 \%$ in chiller reduce APCs, Coliforms and Staph.aureus counts by $97.3 \%, 72.01 \%$ and $94.9 \%$ respectively and similar results were recorded by ELsaid et al. (2002). Oliveira et al. (2009) mentioned that gamma radiation 1.5 and $3 \mathrm{KGy}$ on chicken breast reduce APCs from 3.0 \pm 0.01 to less than 1.0 and total Coliforms reduced from $2.9 \pm 0.3$ to $0.3 \pm 0.4$ and Staphaureus to less than $0.5 \quad \log _{10} \quad \mathrm{cfu} / \mathrm{gm}$ respectively. Also Min et al. (2007) reported that no viable cells were detected after exposure of inoculated chicken thigh and breast to $2 \mathrm{KGy}$ radiation. Irradiation with air and vacuum reduce mesophiles from 4 and 3.8 to 3.3 and $2.7 \log _{10} \mathrm{cfu} / \mathrm{gm}$ at $2 \mathrm{KGy}$ and 1.7 and $1.6 \log _{10} \mathrm{cfu} / \mathrm{gm}$ at $3 \mathrm{KGy}$ while Coliforms reduced from 2.2 and $3 \log _{10} \mathrm{cfu} / \mathrm{gm}$ to 0.6 and $0.5 \log _{10} \mathrm{cfu} / \mathrm{gm}$ by $2 \mathrm{KGy}$ and not detected at 3KGy respectively Mantilla et al. (2011). The results recorded by Mohamed et al. (2008) on fish fillets exposed to radiation on APCs, Coliforms and Staph.aureus were in control samples 6.4,2.68 and $2.38 \log _{10} \mathrm{cfu} / \mathrm{gm}$ while at $2 \mathrm{KGy}$ were 2.6 , less than 3 and less than $2 \log _{10} \mathrm{cfu} / \mathrm{gm}$ and at $3 \mathrm{KGy}$ were 2.1, less than 3 and less than $2 \log _{10} \mathrm{cfu} / \mathrm{gm}$ respectively.

Therefore this study focused on the effect of Chlorine, Hydrogen peroxide and Irradiation on bacterial population, Coliforms and Staph.aureus in whole chicken carcasses from a local poultry plant with comparison between the three methods.

\section{MATERIALS and METHODS}

Total number of 80 broiler chicken carcasses from an automatic poultry slaughtering plant in Dakahlia, Egypt were collected after complete preparation (slaughtering, scalding, defeathering and evisceration), just afterwashing in the chiller where they divided into four groups. The first group [control group] were placed in a chiller containing cold water for 60 minutes and left as a control.

The second group were divided into two subgroup (each one ten carcasses) one of them rinsed with $25 \mathrm{ppm}$ chlorine (sodium hypochlorite $14 \%$ vol./vol.) and the other one rinsed with $50 \mathrm{ppm}$ chlorine for three minutes then sampling.

The third group were also divided into two subgroup (each oneten carcasses) one of them rinsed with $1 \%$ hydrogen peroxide and the other one rinsed with $2 \%$ hydrogen peroxide for two minutes.

The fourth group divided into two subgroups (each one ten carcasses), $250 \mathrm{gm}$ from each carcass were packed in a sterile polyethylene bags heat sealed then irradiated at National Center for Radiation Research and Technology (NCRRT) Nasr City, Cairo. The irradiation source was Cobalt 60 irradiation model ISS LEDDVATED. The dose rate was established using alanine transfer dosimeter and variation in the absorption of irradiation dose was minimized by placing the samples within a uniform area of the irradiation field. One subgroup exposed to $2 \mathrm{KGy}$ and the other subgroup exposed to $3 \mathrm{KGy}$ of gamma rays. After irradiation $25 \mathrm{gm}$ of each exposed samples were homogenized with $225 \mathrm{ml}$ of $0.1 \%$ peptone water in a stomacher for 2.5 minutes at 3000rpm followed by ten fold serial dilution in $0.1 \%$ peptone water Each of the prepared samples were examined for enumeration of its microorganisms content as follows.

\section{1-Total Colony Count:}

$0.1 \mathrm{ml}$ of each dilution was evenly spread over the dry surface of standard plate count agar using a sterile bent glass spreader only plates contain 30-300 colonies were counted as the total colony per gram of samples according to APHA (1985).

\section{2-Coliform Count:}

Using most probable number technique (MPN) according to ICMSF (1978).

\section{3- Staph. Aureuscount:}

Using Baired Parker agar medium with eggyolk tellurite emulsion APHA (1992).

\section{Biochemical Identification of Staph.aureus;}

Identification of Staph.aureus according to APHA (1992); films were prepared from the pure culture of isolated organisms stained with Gram's stain and examined microscopically for $\mathrm{G}+\mathrm{ve}$ cocci.

The tests for identification were motility, catalase test, mannitol test and coagulase test (tube method). 


\section{RESULTS}

Table 1: Statistical analytical results for effect of chlorine on decontamination process.

\begin{tabular}{lccc}
\hline $\begin{array}{l}\text { Microbial count log } \\
\text { mean } \pm \text { S.E. }\end{array}$ & control & $\begin{array}{c}\text { after decontamination } \\
\text { with } 25 \mathrm{ppm} \text { chlorine }\end{array}$ & $\begin{array}{c}\text { after decontamination } \\
\text { with 50 ppm chlorine }\end{array}$ \\
\hline APC & $5.73 \pm 3.23$ & $5.71 \pm 3.08^{*}$ & $5.62 \pm 3.57^{*}$ \\
\hline MPN & $3.74 \pm 1.45$ & $3.69 \pm 1.07^{*}$ & $3.55 \pm 1.44^{*}$ \\
\hline Staph.aureuscount & $3.62 \pm 1.59$ & $3.58 \pm 1.17^{*}$ & $3.6 \pm 1.1^{*}$ \\
\hline
\end{tabular}

$\mathrm{APC}=$ aerobic plate count $\& \mathrm{MPN}=$ most probable number of coliforms \& Staph.aureus=staphylococcus aureus count, $\mathrm{NG}=\mathrm{no}$ growth.

- Means results of decontamination are significantly different $(\mathrm{P}<0.05)$

Table 2: Statistical analytical results for effect of hydrogen peroxide on decontamination process.

\begin{tabular}{lccc}
\hline $\begin{array}{l}\text { Microbial countlog } \\
\text { mean } \pm \text { S.E. }\end{array}$ & control & $\begin{array}{c}\text { after decontamination } \\
\text { with } 1 \% \mathrm{H}_{2} \mathrm{O}_{2}\end{array}$ & $\begin{array}{c}\text { after decontamination } \\
\text { with } 2 \% \mathrm{H}_{2} \mathrm{O}_{2}\end{array}$ \\
\hline APC & $5.73 \pm 3.23$ & $5.34 \pm 2^{*}$ & $5.20 \pm 2.47^{*}$ \\
\hline MPN & $3.74 \pm 1.45$ & $3.53 \pm 1.46^{*}$ & $3.30 \pm 1.04^{*}$ \\
\hline Staph.aureuscount & $3.62 \pm 1.59$ & $3.44 \pm 1^{*}$ & $3.30 \pm 1.07^{*}$ \\
\hline
\end{tabular}

Table 3: Statistical analytical results for effect of gamma rays irradiation on decontamination process.

\begin{tabular}{lccc}
\hline $\begin{array}{l}\text { Microbial countlog } \\
\text { mean } \pm \text { S.E. }\end{array}$ & Control & $\begin{array}{c}\text { after decontamination } \\
\text { with } 2 \mathrm{KGy}\end{array}$ & $\begin{array}{c}\text { after decontamination } \\
\text { with 3KGy }\end{array}$ \\
\hline APC & $5.73 \pm 3.23$ & $4.92 \pm 2.11^{*}$ & $4.80 \pm 0.1^{*}$ \\
\hline MPN & $3.74 \pm 1.45$ & $2.87 \pm 0.1^{*}$ & $\mathrm{NG}^{*}$ \\
\hline $\begin{array}{l}\text { Staph.aureus } \\
\text { Count }\end{array}$ & $3.62 \pm 1.59$ & $2.93 \pm 0.01^{*}$ & $\mathrm{NG}^{*}$ \\
\hline
\end{tabular}

\section{DISCUSSION}

The sanitary evaluation of slaughtered birds is based mainly on its microbial findings and level of contamination. Many investigators proved that more than $70 \%$ of poultry carcasses are contaminated and the microbial count being more than $3 \times 10^{5} \mathrm{cfu} / \mathrm{ml}$, Tamblyn et al. (1997).

Table (1) shows that the mean $\log _{10} \mathrm{cfu} / \mathrm{gmv}$ alues of APCs in examined control samples, after decontamination with $25 \mathrm{ppm}$ and $50 \mathrm{ppm}$ chlorine were $5.73 \pm 3.23,5.71 \pm 3.08$ and $5.62 \pm 3.57$ $\log _{10} \mathrm{cfu} / \mathrm{gm}$. while MPN count were $3.74 \pm 1.45$, $3.69 \pm 1.07$ and $3.55 \pm 1.44 \log _{10} \mathrm{cfu} / \mathrm{gm}$ and the counts of Staph.aureus were $3.62 \pm 1.59,3.58 \pm 1.17$ and $3.6 \pm 1.1 \log _{10} \mathrm{cfu} / \mathrm{gm}$ respectively, the results in control samples nearly in accordance with Bryan (1980), Tamblyn et al. (1997); Mahmoud, Hammouda (2006); Mira, Eskandar (2007) and Morsh-dy et al. (2008). The higher microbial load could be attributed to the technique of evisceration and poor hygienic levels. The reduction were more than those reported by Whyte et al. (2001) and similar to Gelis, Kabul (2006); Stopforth et al. (2007) and Karen et al. (2010) the difference in reduction may be due to the final processing and rinsing before decontamination process. The results were reduced significantly when compared statistically with corresponding controls $(\mathrm{P}<0.05)$.

Table (2): The results of decontamination with hydrogen peroxide $\left(\mathrm{H}_{2} \mathrm{O}_{2}\right)$ declared that. The mean $\log \mathrm{cfu}$ value of APCs were 5.73 $\pm 3.23,5.34 \pm 2$, and $5.20 \pm 2.47 \log _{10} \mathrm{cfu} / \mathrm{gm}$ after decontamination with hydrogen peroxide $1 \%$ and $2 \%$ respectively while MPN count were $3.74 \pm 1.45,3.53 \pm 1.46$ and $3.30 \pm 1.04$ $\log _{10} \mathrm{cfu} / \mathrm{gm}$ and the counts of Staph.aureus were $3.62 \pm 1.59,3.44 \pm 1$ and $3.30 \pm 1.07 \quad \log _{10} \mathrm{cfu} / \mathrm{gm}$ respectively similarly with those recorded by Bolder (1997); Northcutt, Jones (2004); Black et al. (2008) and Hugas; Tsigarida (2008), higher results recorded 
by EL-Said et al. (2002) and Mostafa (2010), while the reduction after $2 \% \mathrm{H}_{2} \mathrm{O}_{2}$ were similar to Northcutt, Jones (2004) and lower than the results recorded by Mostafa (2010). The results were reduced significantly when compared with corresponding controls $(\mathrm{P}<0.05)$.

The results in Table (3) declared that the mean log cfu value of APCs were 5.73 $\pm 3.23,4.92 \pm 2.11$ and $4.80 \pm 0.1 \log _{10} \mathrm{cfu} / \mathrm{gm}$ in examined control samples, after irradiation with $2 \mathrm{KGy}$ and $3 \mathrm{KGy}$ respectively while MPN count were 3.74 $\pm 1.45,2.87 \pm 0.1 \quad \log$ ${ }_{10} \mathrm{cfu} / \mathrm{gm}$ respectively in control samples and after irradiation with $2 \mathrm{KGy}$ and no growth after irradiation with $3 \mathrm{KGy}$ and the counts of Staph.aureus were 3.62 \pm 1.59 and $2.93 \pm 0.05 \log _{10} \mathrm{cfu} / \mathrm{gm}$ respectively in examined control samples and after irradiation with 2KGy and no growth after irradiation with $3 \mathrm{KGy}$ the reduction after irradiation nearly similar to Mohamed et al. (2008); Oliveira et al. (2009) and Mantilla et al. (2011), while higher reduction recorded by Min et al. (2007) the reduction after irradiation in APC in addition to no growth of Coliforms and Staph.aureus were similarly to Mohamed et al. (2008); Oliveira et al. (2009) and Mantilla et al. (2011). The effects of irradiation as log viable counts of all the inspected bacteria showed gradual reduction as the irradiation dose increased. The results were reduced significantly when compared with corresponding controls $(\mathrm{P}<0.05)$.

In conclusion from the aforementioned results declared that chlorine is a bactericidal, viricidal and fungicidal agent can be successfully applied in the food industry and may conistitute an important factor in reducing losses resulting from food spoilage and human infection.

The use of hydrogen peroxide in chiller used for chicken chilling prior to its packaging greatly reduce its bacterial load. It is a power full sanitizer for poultry carcasses, it enhances its meat quality.

Radiation did not affect the sensory character of chicken carcasses and produces no apparent changes in the organoleptic characteristics, it inhibit microbial growth and so extends the shelf life of the product. From the results it was obvious that the microbial reduction was greater after radiation than after hydrogen peroxide and after hydrogen peroxide than after chlorine.

\section{REFERENCES}

APHA (American Public Health Association) (1985): Compendium of methods for microbiological examination of methods for microbiological examination of food $2^{\text {nd }} \mathrm{Ed}$. Washington, DC. International Commission on Microbiological Specification for Food.
APHA (1992): Compendium of methods for the microbiological examination of food, $3^{\text {rd }} \mathrm{Ed}$., American Public Health Association, Washington, DC.

Black, D.G.; Tylor, T.M.; Kerr, H.J.; Padh, I.S.; Montiulle, T.J. and David son, P.M. (2008): Decontamination of fluid milk containing bacillus spores using commercial house hold products. J. Food Protection. 71: 471-473.

Bryan, F.L. (1980): Food borne disease in the United States associated with meat and poultry. J. Food Protection. 43: 140-146.

Bolder, N.M. (1997): Decontamination of meat and poultry carcasses. Tends Food Sci. \& Technol. 8: 221-227.

EL-Said, A.E.; Morshdy, A.M. and Sallam, K.I. (2002): Improving the sanitary status of broiler carcasses during their processing. $6^{\text {th }}$ Vet. Med. Zag. Conference Egypt.

Gelis Tarihi and Kabul Tarihi (2006): Effects of application ozone and chlorine on microbiological load in slaughter houses of broiler carcasses. Uludag Univ. J. Fac. Vet. Med. 1-2: 7-11.

Hugas, M. and Tsigarida, E. (2008): Pros and Cons of carcass decontamination; The role of carcass decontamination; The role of Europian food safety authority, Meat Sci. 78: 43-52.

ICMSF (1978): Microorganisms in foods, their significance and methods of enumeration. $2^{\text {nd }}$ Ed. Toronto, Univ. of Toronto Press Canada.

Ismail, S.A.; Dea, T.; Abd EL-Rahman, H.; Yassien, M.N. and Beuchat, L.R. (2001): Effectiveness of immersion treatment with acids on reducing population of Yarrowia lipolytica on raw chicken. Int. J. Food Microbiol. Feb., 28: 6472.

Kanatt, S.R.; Chander, R. and Sharma, A. (2005): Detection of food treated with ionizing radiation. Meat Sc. 69: 269-275.

Karen, M.K.; Aditi, K.; Andy, I.B. and Craig, G.C. (2010): Validation of $2 \%$ lactic acid antimicrobial rinse for mobile poultry slaughter operation. J. Food Protection, 73; 11: 2079-2083.

Mahmoud Y. ELA. and Hammouda, N. Seham (2006): Quality evaluation of poultry meat carcasses in EL-Gharbia Governorate markets. Assiut Vet. Med. J. 52, 110: 31-43.

Mantilla, S.P.S.; Santos, E.B.; Vital, H.C.; Mano, S.B.; Freitas, M.Q. and Franco, R.M. (2011): Microbiology, sensory evaluation and shelf life of irradiated chicken breast fillets stored in or vacuum. Brazilian Archives of biolog and technolog, 54, 3: 569-576.

May, K.N. (1974): Changes in microbial numbers during final washing and chilling of commercially slaughtered broilers. Poultry Sc. 53: $1282-1285$. 
Min, J.S.; Lee, T.A.; Jo and Leet, M. (2007): Control of microorganisms and reduction of biogenic amines in chicken breast and thigh by irradiation and organic acids. Poultry Sci. 86: 2034-2041.

Mira, K.I. Enshrah and Eskander, A.A. (2007): Bacteriological Assessment of freshly slaughtered chicken and Atrial for improvement. Assiut Vet. Med. J. 53, 113: 88100.

Mohamed, S. Wafaa; Mira, K.I. Enshrah and AbouZied, Z.A. Suzan (2008): Effect of trisodium phosphate and low dose irradiation treatments on the bacteriological, chemical and sensory status of frozen fish fillets. Assiut Vet. Med. J. 54; 116: 144-157.

Morshdy, A.M.A.; Hafez, A.E.; Mostafa, A.M. and EL-Sayed, Ola, A. (2008): Bacterial evaluation of marketed chicken carcasses in Dakahlia Province and improvement with lactic acid. Zag. Vet. J. 36, 5: 93-100.

Mostafa, N.Y. (2010): Effectiveness of immersion treatments with hydrogen peroxide in reducing microbial population on raw chicken carcasses. Global Veterinaria. 4, 4: 362-365.

Northcutt, J.K. and Jones, D.R. (2004): Asurvey of water use and common industry practices in commercial broiler processing facilities. J. Appl. poultry Res. 13: 48-54.

Oliveira, AL.; Pereira, M.T.; Bueno, P.H.S. and Oliveira, RB.P. (2009): Microbiological evaluation of chicken breast irradiated in conventional and vacuum package. Arq. Bras. Med. Vet. Zootec, 61: 1210-1217.

Pelezar, J.M.J.; Chan, E.C.S. and Krieg Noel, R. (1997): Microbiologia; Conceitose aplicacoes. $2^{\text {nd }}$ ed V.Z., Makron Books, Sao Paulo.

Stopforth, J.D.; O Connor, R.; Lopes, M.; Kollapalli, B.; Hill, W.E. and Samadpour, M. (2007): Validation of individual and multiple tensequential interventions for reduction of microbial populattions during processing of poultry carcasses. J. Food Protection. 70: 1393-1401.

Tamblyn, K.C.; Conner, D.C. and Bipgipi, S.F. (1997): Utilization of skin attachment model to determine the antibacterial efficacy of potential carcasses treatment. Poultry Sci. sep., 76: 7986.

Thayer, D.W.; Fox, J.B. and Lakritz, L. (1993): In; Amer. Chem. Soc. [ACS] Symp. Ser. vol. 528, 293-298. Washington, DC.

Whyte, P.; Collins, J.D.; McGill, K.; Monahan, C. and $O$ Mahony, H. (2001): Quantitative investigation of the effect of chemical decontamination procedures on the microbiological status of broiler carcasses during processing. J. Food Protection 64, 2: 179-183.

Zahra, A. (2001): Microbial. Association in cool stored poultry. decontamination. M.V.Sc. Thesis Fac. Vet. Med. Zag. Univ. Egypt.

\footnotetext{
تأثير الإشعاع وماء الأكسجين والكلور على إزالة التلوث البكتيري لأبائح بدارى التسمين

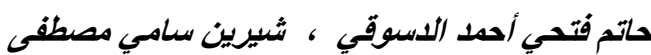

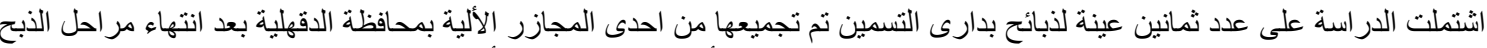

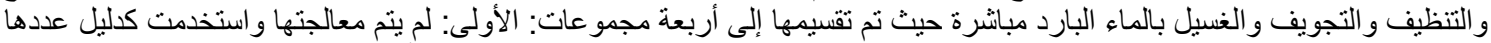

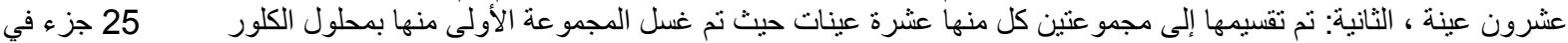

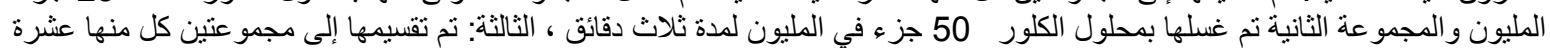

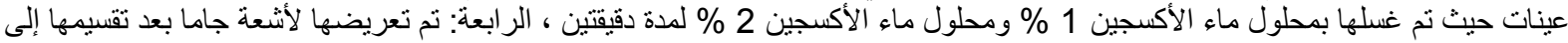

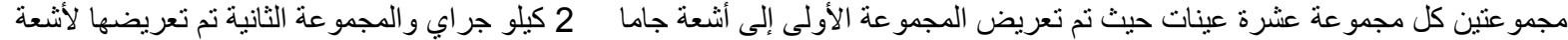

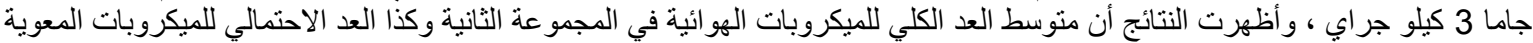

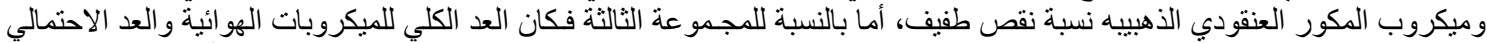

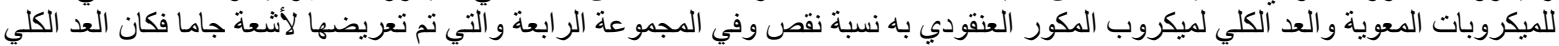

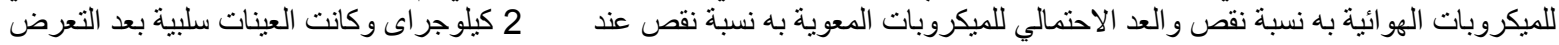

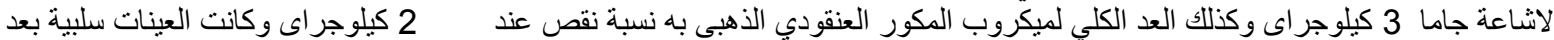

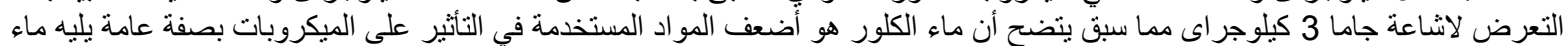
الأكسجين ثم أشعة جاما و التي أظهرت أعلى نأثير دون أن تغير في الصفات الطبيعية للحوم المعرضة للأشعة.
} 